防食技術，23，341-346(1974)

\title{
各種ステンレス鋼の耐硫酸性*
}

\author{
安保秀雄**, 上田全紀***, 野口栄** \\ **新日本製鉄（株）八幡製鉄所技術研究所 \\ ***新日本製鉄（株）本社研究開発本部生産技術研究所
}

\section{Corrosion Resistance of Various Stainless Steels \\ to Sulfuric Acid Solution}

\author{
Hideo Abo,** Masanori Ueda*** and Sakae Noguchi** \\ **Technical Research Institute, Yawata Workds, Nippon Steel Corp. \\ ***Process Technology R. \& D. Laboratories, Nippon Steel Corp.
}

\begin{abstract}
It is well-known that some stainless steels are passive and others are active in dilute sulfuric acid solution. Corrosion behavior, especially passivation, of various stainless steels is investigated in sulfuric acid solution by the measurements of weight loss, corrosion potential and anodic polarization curves at various temperatures and concentrations. From these results, passivation is the most important factor for selecting a suitable stainless steel in sulfuric acid solution. Passivation is influenced by alloying element, temperature and concentration of sulfuric acid. Chromium is the most effective element for enlargement of passivation region. Molybdenum and copper are both effective. On the other hand, chromium increases dissolution rate in active state but molybdenum reduces it. With increase of temperature, passivation is difficult to occur and active dissolution rate becomes high. So temperature control is very important. In sulfuric acid solution, cathodic process is the reduction of hydrogen ions and this process is affected by temperature, concentration of sulfuric acid solution and alloying elements. In some cases, some stainless steels can be passivated by the cathodic hydrogen reduction process. High chromium and molybdenum containing stainless steels are desirable for passivation by the cathodic process. On the other hand, for stainless steels showing active dissolution, the corrosion rate is controlled by the cathodic hydrogen reduction process.
\end{abstract}

\section{1. 緒 言}

排煙脱硫装置の必要性に関連して各種ステンレス鋼の 耐硫酸性を検討した。従来からステンレス鋼の耐硫酸性 に関する研究は多いが，ステンレス鋼がどの程度の硫酸 濃度, 温度まで使用しらるか否かという点についての研 究は少ない。そこで今回は，硫酸中での不働態域の広さ という考方方で各種のステンレス鋼について硫酸濃度, 温度を变えて検討した。不働態域の決定には浸漬腐食試 験, 自然電位の測定ならびに分極曲線の測定を用いた。 ステンレス鋼の耐硫酸性に関する従来の研究1)通し て硫酸中でのステンレス鋼の耐食性に関する考方方はほ 淮明らかであり, 酸化剤の存在で不働態を生ずる場合に は安定した耐食材料となりうる。一方, 耐硫酸性のすぐ れた材料の研究も多く,オーステナイトステンレス鋼に 対する $\mathrm{Mo}$ や $\mathrm{Cu}$ の効果 ${ }^{2}$ 抢よび $25 \% \mathrm{Cr}$ 鋼での $\mathrm{Ni}, \mathrm{Mo}$

* 昭和 48 年 5 月；第 20 回腐食防食討論会に発 **,*** 表 805 北九州市八幡区枝光 1-1-1 (1-1-1, Eda-

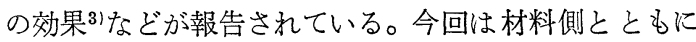
腐食雾囲気の変動と不働態の成否を中心に, 硫酸水溶液 中のステンンス鋼の使用限界を検討し，鋼種による差を 明らかにした。

\section{2. 実験方法}

実験に使用した供試材は Table 1 に示す 8 鋼種であ る。 JIS 規定の含 Mo 鋼種を中心にし, 合金元素の効果 を調査するため Mo の高い $17 \mathrm{Cr}-15 \mathrm{Ni}-5 \mathrm{Mo}$ (SUS 317 Mo), Si の高い $17 \mathrm{Cr}-13 \mathrm{Ni}-3.5 \mathrm{Si}-0.8 \mathrm{Cu}$ (YUS 110), $\mathrm{Cr}$ や $\mathrm{N}$ の高い $25 \mathrm{Cr}-13 \mathrm{Ni-0.7} \mathrm{Mo-0.3} \mathrm{N} \mathrm{(YUS} \mathrm{170)}$ についても検討した。腐食試験片は 6 15 $\mathrm{mm}$ 厚板成品 板の板厚中心部より $3 \times 30 \times 30 \mathrm{~mm}$ を切り出し, \#600 までペーパー研磨後脱脂洗浄し腐食試験に供した。腐食 液は試薬特級硫酸と蒸留水を用い, 原則として $0.1,0.5$, $1,5,10,30,50 \%$ 硫酸溶液を作成した。腐食試験は逆流 コンデンサーつきのフラスコにて実施し，20,40,60, $80^{\circ} \mathrm{C}$ は恒温槽を使用し, さらに沸騰での試験も実施し 
Table 1. Chemical composition of stainless steels used in corrosion studies.

\begin{tabular}{|c|c|c|c|c|c|c|c|c|c|c|}
\hline \multirow[b]{2}{*}{ Alloy } & \multicolumn{10}{|c|}{ Chemical composition (wt \%) } \\
\hline & C & Si & $M n$ & $\mathbf{P}$ & $\mathbf{s}$ & Cr & $\mathrm{Ni}$ & Mo & Cu & $\mathbf{N}^{-}$ \\
\hline SUS 304 & 006 & 076 & 1.08 & 0027 & 0008 & 1830 & 900 & -1 & - & - \\
\hline SUS 316 & 006 & 056 & 164 & {$[0022$} & 0011 & 1660 & 1300 & 236 & - & - \\
\hline SUS $316 \mathrm{~J}_{1}$ & 006 & 072 & 091 & 0017 & 0004 & 1770 & 1310 & 212 & 194 & - \\
\hline SUS $317 \mathrm{~L}$ & 0.028 & 075 & 163 & 0024 & 0008 & 1860 & 1450 & 335 & - & - \\
\hline SUS $317 \mathrm{Mo}$ & 004 & 062 & 158 & 0024 & 0006 & 1728 & 1535 & 506 & $=$ & - \\
\hline SUS $329 J_{1}$ & 004 & 089 & 060 & 0011 & 0011 & 2360 & 650 & 128 & - & - \\
\hline YUS 110 & 004 & 3.29 & 063 & 0010 & 0004 & 1638 & 1251 & $=$ & 074 & - \\
\hline YUS 170 & 005 & 073 & 154 & 0015 & 0005 & 2433 & 1288 & 071 & - & 033 \\
\hline
\end{tabular}

た。鋼種によっては異なる濃度, 温度の硫酸溶液中でも 試験を追加した。試験時間は $24 \mathrm{hr}$ であり, 腐食減量か ら腐食速度を求めた。他方 SUS 304, SUS 316, SUS $316 \mathrm{~J}_{1}$, YUS 170 を使用し, 耐食域内外の硫酸濃度, 温 度を選んで自然電位や陽分極曲線，陰分極曲線の測定を 実施した。掃引速度はいずれも $50 \mathrm{mV} / \mathrm{min}$ である。測 定溶液は腐食試験と同様, 試薬特級硫酸と蒸留水を用い て調合し空気開放の条件で測定した。硫酸水溶液中での ステンレス鋼の挙動に関して，電気化学的測定から主と
して次のような情報を得た。

（1）各種ステンレス鋼の種々な硫酸濃度, 温度条件 下での自然電位の測定。

（2）（1）の測定後陽分極曲線の測定。

(3) 自然電位の経時変化と陰極還元の効果。

（4）不働態化後の陰分極挙動。

これらをもとに硫酸溶液中でのステンレス鋼の腐食挙動 を考察した。

\section{3. 実 験 結 果}

\section{1 浸漬腐食試験結果}

Fig. 1 の (A) (H) は, 供試材の硫酸濃度-温度と腐 食速度を眓示したものである。各図の境界線は腐食速度 が $0.1 \mathrm{~g} / \mathrm{m}^{2} \cdot \mathrm{hr}, 1 \mathrm{~g} / \mathrm{m}^{2} \cdot \mathrm{hr}, 10 \mathrm{~g} / \mathrm{m}^{2} \cdot \mathrm{hr}$ 相当するもの で，ここでは $0.1 \mathrm{~g} / \mathrm{m}^{2} \cdot \mathrm{hr}$ 以下を十分使用可能範囲とし て，仮りに浸漬試験による不㗢態域と考えた。Fig.1(A) は SUS 304 の結果である。 $0.1 \mathrm{~g} / \mathrm{m}^{2} \cdot \mathrm{hr}$ に相当する硫酸 濃度一温度以下の条件ではすぐれた耐食材料となりらる。 (B) は YUS 110 の結果で, $\mathrm{Si}, \mathrm{Cu}, \mathrm{Ni}$ の添加で不働態
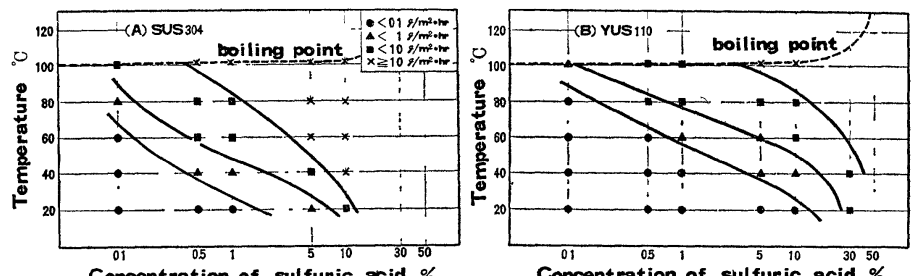

Concentration of sulfuric acid \%

Concentration of sulfuric acid
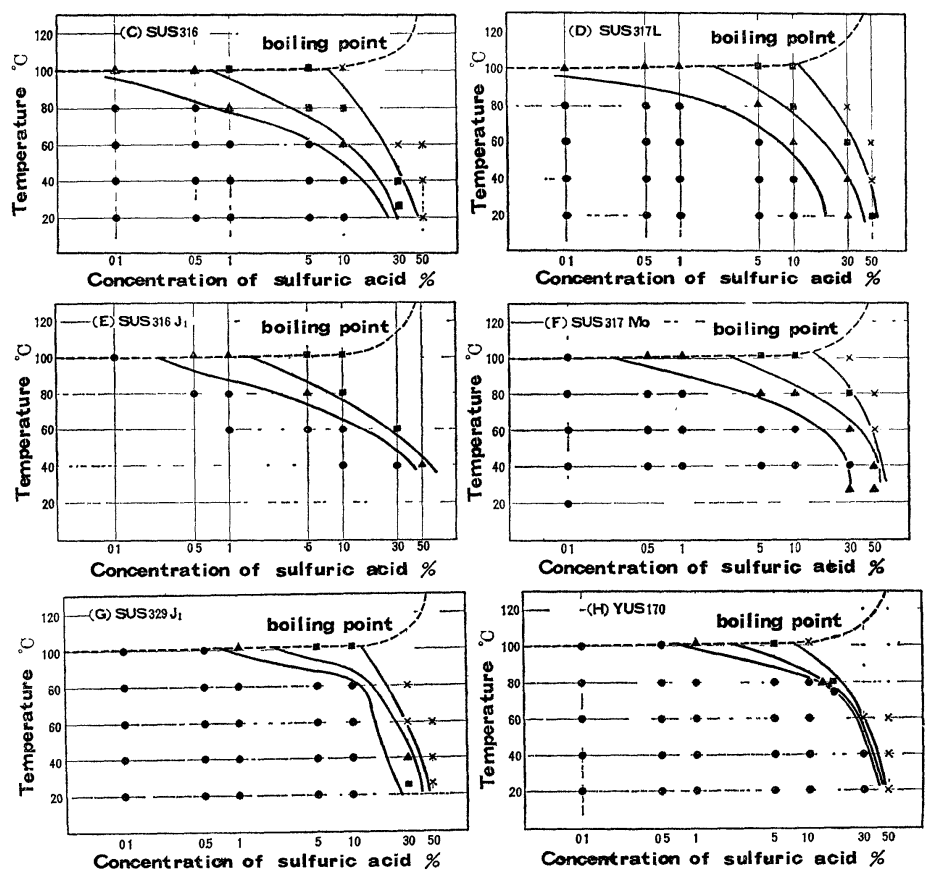

Fig. 1. Resistance of various stainless steels to sulfuric acid solution. 
域はやや広くなる。(C),(D) はSUS 316, SUS 317 L の 結果で, Mo の添加は大幅に不働態域の広さを増し, 硫 酸に対する使用可能域は大きくなる。(E), (F) は SUS $317 \mathrm{Mo}$, SUS $316 \mathrm{~J}_{1}$ の結果である。Mo の効果で不働態 域は広いが，Moを単独に 5\% まで増してもさほど不働 態域を広げる効果はなく，むしろ $2 \% \mathrm{Mo}+2 \% \mathrm{Cu}$ の 添加された SUS $316 \mathrm{~J}_{1}$ のほうが不働態域は広くなる。 この結果, 耐硫酸性, とくに不働態域の広さにはMo $\mathrm{Cu}$ の添加が有効であることがわかる。Mo の高い鋼種 は後述すると拈り活性域での腐食速度を顕著に低下させ る。Fig. 1 (G), (H) は高 Cr の二相鋼とオーステナイト ステンレス鋼の結果で, これらは供試材中最も不働態域 が広い。YUS 170 はオーステナイト組織であり, SUS $329 \mathrm{~J}_{1}$ はオーステナイトとフェライトの二相組織である が，これら組織の差は耐硫酸性には関係しないようであ る。こうして希硫酸中のような, ステンレス鋼に不働態 が起こりらるような条件下では, 耐硫酸性に対して Cr の効果が最も大きい。ただ別報4で述べたと扮り，単に 高 $\mathrm{Cr}$ たシけではこのような $\mathrm{Cr}$ の効果は十分発揮されず, 必ず Mo や Ni の共存が必要である。一方，高 $\mathrm{Cr}$ 鋼は 活性域での溶解速度が大きく,50\%硫酸では SUS 317L, SUS $316 \mathrm{~J}_{1}$ 等のほうが腐食速度は小さい。すなわち， 従来より知られている Cr の耐酸性劣化は活性域での 現象に限って成立するといえる。これらの図から明らか なことは，不働態域がせまい，SUS 304 では腐食速度が 徐々に增大する領域が明白に区別されるのに対して，不 働態域の広、鋼種では腐食速度の小さい領域と大きい領 域とがきわめて近接している事実である。これはステン レス鋼の耐食性が不働態に依存するためで，したがって 高 $\mathrm{Cr}$ 鋼の選定にあたってはこの点注意する必要があ ろう。これらの結果から, 不㗢態を生じない上うな $10 \%$ $\mathrm{H}_{2} \mathrm{SO}_{4}$ 沸騰, $30 \% \mathrm{H}_{2} \mathrm{SO}_{4} 60^{\circ} \mathrm{C}, 50 \% \mathrm{H}_{2} \mathrm{SO}_{4} 40^{\circ} \mathrm{C}$ のよ

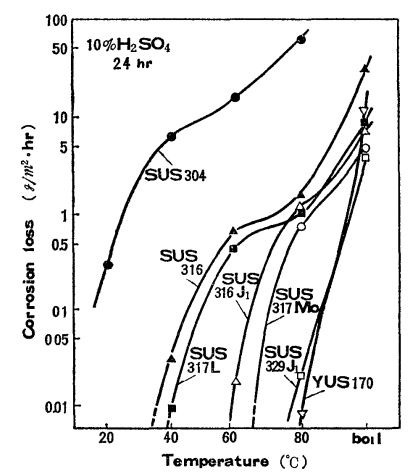

Fig. 2. Effect of temperature on the corrosion loss of various stainless steels in sulfuric acid solution.
うな条件では，ステンレス鋼はいずれも耐食材料とはな りえない。Fig. 2 は $10 \%$ 硫酸溶液中での腐食速度に対 する温度の影響を示して扣り，各鋼種の不働態から活性 態への移行の様子，したがって不働態の広さに対する温 度の影響を示している。硫酸中での不働態生成の範囲や 不働態をはみ出した場合の腐食に対して温度の影響はき わめて大きく, 温度 $10^{\circ} \mathrm{C}$ の増大で 2 倍から 20 倍にも腐 食速度が増大する。したがって使用時の温度管理は最も たいせつである。Fig. 3 はほ涪活性溶解域に相当する沸 騰状態の硫酸溶液中の挙動で, 硫酸濃度の影響を示して いる。硫酸濃度が倍になれば腐食速度もほぼ倍になる。 Mo の多い鋼種は他鋼種よりも活性域での腐食速度が小 さい。

以上の結果から, 使用環境の硫酸濃度, 温度がわかれ ば使用可能なステンレス鋼の選択は可能となる。次に異 種ステンレス鋼の接触の影響を検討した。結果は Table 2 のと怙りで, 単独の場合には不衝態になるステンレス 鋼と不働態にならないステンレス鋼を接触させると，不 働態になるべきステンレス鋼が接触によって腐食を起こ 乙, 他方のステンレス鋼は単独の場合よりも腐食速度は 減少する。これは次節で述べる電位測定結果や分極曲線 を考慮すれば十分考えられることである。したがって硫

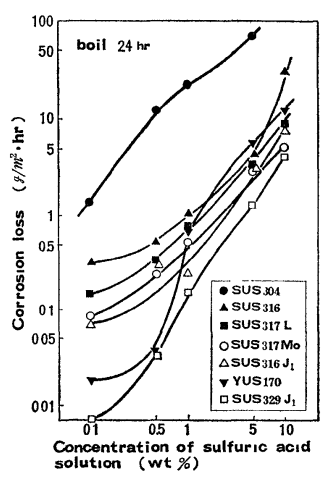

Fig. 3. Effect of concentration of sulfuric acid solution on the corrosion loss of various stainless steels.

Table 2. Change of the corrosion loss when coupled with different stainless steels in sulfuric acid solution.

\begin{tabular}{|c|c|c|c|}
\hline $\begin{array}{l}\text { Steels } \\
\text { coupled }\end{array}$ & Test condition & $\begin{array}{c}\text { Corrosion loss } \\
\text { when coupled } \\
\mathrm{g} / \mathrm{m}^{2} \cdot \mathrm{hr}\end{array}$ & $\begin{array}{c}\text { Corrosion loss } \\
\text { when separated } \\
\mathrm{g} / \mathrm{m}^{2} \cdot \mathrm{hr}\end{array}$ \\
\hline SUS 304 & \multirow{2}{*}{$\begin{array}{c}10 \% \mathrm{H}_{2} \mathrm{SO}_{4} \cdot 60^{\circ} \mathrm{C} \\
24 \mathrm{hr}\end{array}$} & 55 & 269 \\
\hline Sus $329 J_{1}$ & & 0.3 & 0.0 \\
\hline \multirow{2}{*}{$\begin{array}{c}\text { SUS } 316 \\
1 \\
\text { SUS } 329 J_{1}\end{array}$} & \multirow{2}{*}{$\begin{array}{c}10 \% \mathrm{H}_{2} \mathrm{SO}_{4} \cdot 80^{\circ} \mathrm{C} \\
24 \mathrm{hr}\end{array}$} & 1.7 & 1.6 \\
\hline & & 05 & 00 \\
\hline
\end{tabular}


酸中でのステンレス鋼の使用にあたっては，不働態化す るものとしないものの接触は好ましくない。

\section{2 電気化学的な測定結果}

3.1 では硫酸溶液中の浸漬腐食試験にもとづき鋼種ご とに耐食域を決定した。この際われわれは, 腐食速度 $0.1 \mathrm{~g} / \mathrm{m}^{2} \cdot \mathrm{hr}$ 以下をかりに不働態と考えた。ここでは種 々な硫酸水溶液中でのステンレス鋼の腐食挙動を電気化 学的な手法で考察した。

まず各種濃度の硫酸水溶液中で 60 分浸漬後の自然電 位を測定した。自然電位は陽分極曲線と陰分極曲線の相 互関係で決まり，したがって鋼種や環境の影響を反映す る。こうして自然電位の測定值をすで求めた Fig. 1 の結果に記入したものが Fig. 4 である。自然電位が貴 な場合には耐食性がすぐれ, 浸漬腐食試験で求めた境界 と自然電位測定值とはよく対応している。また合金元素 の効果も明らかで, $\mathrm{Cr}, \mathrm{Mo}, \mathrm{Cu}$ 等を合金したものでは 硫酸濃度, 温度が高くても貴な自然電位を示す。Fig. 5 は自然電位と腐食速度の関係を SUS 304, SUS 316 につ いて示した山ので, 自然電位が卑なほど腐食速度は大き $<, 2 \mathrm{~g} / \mathrm{m}^{2} \cdot \mathrm{hr}$ 以上の腐食速度は自然電位が注淁 $-0.30 \mathrm{~V}$ (SCE) 以下の卑な場合に対応し, 一方 $0.1 \mathrm{~g} / \mathrm{m}^{2} \cdot \mathrm{hr}$ 以
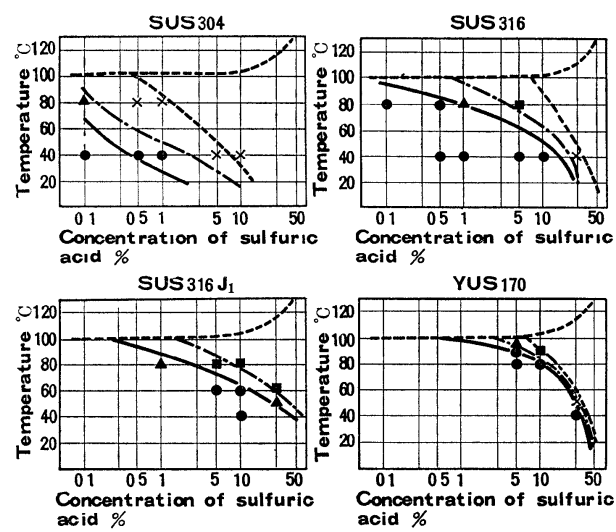

Fig. 4. Relation between corrosion potentials and corrosion loss of various stainless steels in sulfuric acid solution.

\begin{tabular}{cl}
\hline & $\begin{array}{c}\text { Corrosion potential } \\
\mathrm{V}(\mathrm{SCE})\end{array}$ \\
\hline$\quad$ more noble than -0.10 \\
$\quad-0.10 \sim-0.20$ \\
$\mathbf{a}-0.20 \sim-0.30$ \\
$\times \quad$ less noble than -0.30 \\
\hline
\end{tabular}

Corrosion loss boundary $\mathrm{g} / \mathrm{m}^{2} \cdot \mathrm{hr}$

\begin{tabular}{ll}
$\mathrm{g} / \mathrm{m}^{2} . \mathrm{hr}$ \\
\hline- & less than 0.1 \\
.-- & less than 1.0 \\
$-\cdots$ & less than 10 \\
\hline
\end{tabular}

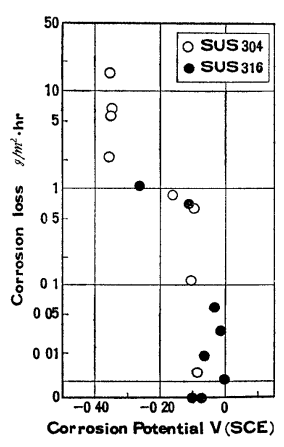

Fig. 5. Relation between corrosion loss and corrosion potential of SUS 304 and SUS 316 in sulfuric acid solution.

Test condition

\begin{tabular}{clc}
\hline Steel & Concentration of $\mathrm{H}_{2} \mathrm{SO}_{4}$ & Temp ${ }^{\circ} \mathrm{C}$ \\
\hline SUS 304 & $0.1,0.5,1,5,10 \%$ & $40^{\circ} \mathrm{C}$ \\
& $0.1,0.5,1 \%$ & $80^{\circ} \mathrm{C}$ \\
\hline SUS 316 & $0.5,1,5,10,30 \%$ & $40^{\circ} \mathrm{C}$ \\
& $0.5,1,5 \%$ & $80^{\circ} \mathrm{C}$ \\
\hline
\end{tabular}

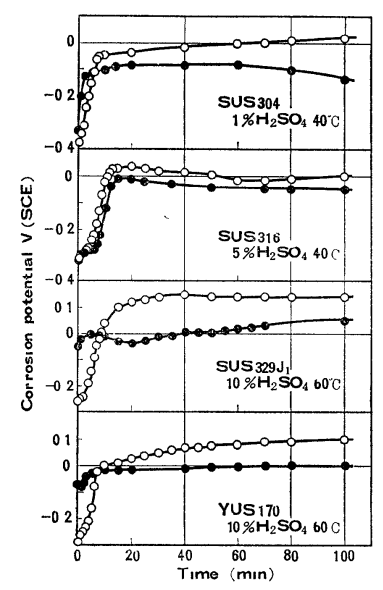

Fig. 6. Change of corrosion potential in sulfuric acid solution showing influence of precathodic reduction.

- - - pre-cathodic reduction at $-0.8 \mathrm{~V}$ (SCE).

下の腐食速度は, 自然電位が $-0.15 \mathrm{~V}$ (SCE) 以上の貴 な電位に対応している。この関係は SUS $316 \mathrm{~J}_{1}$ になる と若干ずれるようになるが，傾向はまったく同じであ る。

こうして自然電位が貴な場合には腐食速度は小さい が，Fig. 6 は硫酸溶液中での自然電位の経時変化を示し ている。SUS 304, SUS 316 では浸漬初期に卑な電位を 示し, 腐食を起こしたのち約 10 分後に貴な電位を示す ようになる。SUS $329 \mathrm{~J}_{1}$ や YUS 170 は浸漬初期から貴 
な電位を示し，多少挙動が異なっている。同図には測定 前に陰極還元した場合も併記した。陰極還元は $-0.80 \mathrm{~V}$ (SCE) で 10 分間括こない, その後電解回路を切って自 然電位を測定した。陰極還元をしたものではいずれも初 期に卑な電位を示したのちしだいに貴な電位を示しここ れがない場合よりもむしろ貴な電位に落ちつくことを示 している。このような条件では, 途中で活性な面がさら されても，短時間で貴な電位に落ちつくことが判明し た。

自然電位を 60 分間測定後陽分極曲線を測定した。す でによく知られていると拈り，硫酸中での分極曲線は安 定な不働態を示するの, 準安定な不働態で negative loop を示すもの，活性溶解を示すものがある。今回の結果の 一例が Fig. 7 で, SUS 304 について硫酸濃度, 温度の 影響を示している。これにより温度, 濃度の変化によっ て活性態から不働態へ移行する様子が明らかである。

Fig. 8 は鋼種の影響を示したもので，前述した浸漬腐食 試験の結果と同様 $\mathrm{Cr}, \mathrm{Mo}, \mathrm{Cu}$ 等の効果が明瞭にみられ る。鋼種や䨌囲気条件を変えて, 陽分極曲線の形から不 働態域の判定を実施した結果を整理すると Table 3 の とおりとなる。SUS 304 では硫酸浱度, 温度ともごく

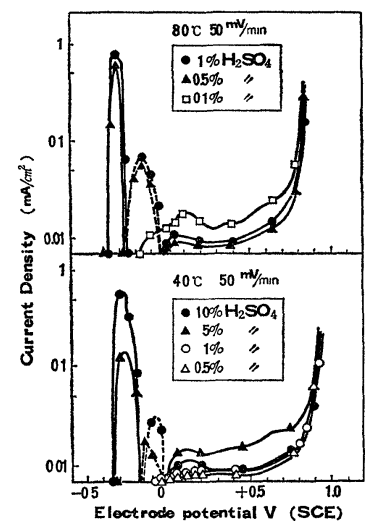

Fig. 7. Change of anodic polarization curves of SUS 304 with concentration of sulfuric acid and temperature.

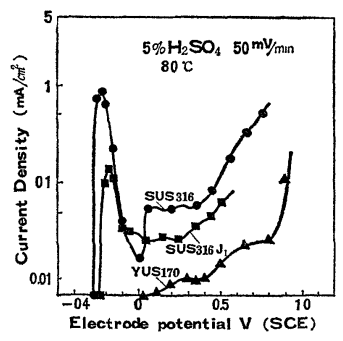

Fig. 8. Anodic polarization curves of various austenitic stainless steels in sulfuric acid solution.
Table 3. Passivation of various stainless steels in sulfuric acid solution.

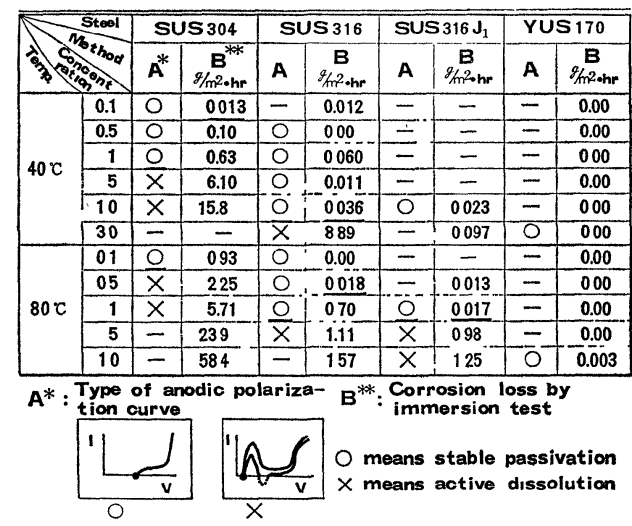

限られた条件でしか不働態化しないが，Mo を含んだ SUS 316 では不働態化する条件が広がり，YUS 170 に なると測定した最もきびしい条件でも安定な不働態を示 す。なお YUS 170 については $80^{\circ} \mathrm{C}$ 以上の条件でも測 定したが，これは Fig. 4 に示してある。このように合 金元素の不働態化に対する効果は顕著にみられ，3.1 で 得られた鋼種による大きな差は不働態成立の難易に依存 することが明らかである。同表には浸漬腐食試験結果も 示したが，両者はほぼ対応している。ただずれる部分も みられ，たとえば分極曲線で不働態を示す条件において も，腐食試験で $1 \mathrm{~g} / \mathrm{m}^{2} \cdot \mathrm{hr}$ 程度の腐食を示すケースもあ る。

前述したとおり， $0.1 \mathrm{~g} / \mathrm{m}^{2} \cdot \mathrm{hr}$ といら腐食速度は自然 電位が $-0.15 \mathrm{~V}(\mathrm{SCE})$ 以上の貴な場合に相当した。今 回の陽分極曲線の測定から，自然電位 $-0.15 \mathrm{~V}$ (SCE) 以上の貴な場合はすべて分極曲線は安定な不働態を示し ている。したがって浸漬試験において $0.1 \mathrm{~g} / \mathrm{m}^{2} \cdot \mathrm{hr}$ とい う数值は, 硫酸溶液中のステンレス鋼が電気化学的にも 安定した不働態になっていることを示しており，局部腐 食のない場合には完全耐食材料の判定基準として大きな 意義を有している。

次に陰分極挙動を測定した。硫酸濃度, 温度を変えた 溶液中で，まず +0.8 V (SCE) で不働態化処理したのち 卑な方向に分極して，陽分極，ついで陰分極挙動を測定 した。Fig. 9 は SUS 304, SUS 316 についての結果で ある。陰極反応としての水素発生反応には液温の影響が

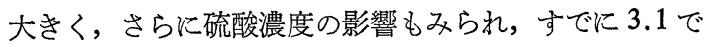
述べた浸漬試験結果に和ける環境側の影響とよく対応し ている。な扮詳細に比較するとSUS 304 と SUS 316 で は挙動が異なり，合金元素によっても院極反応は影響さ れる。すでに Fig. 5 で述べたとおり，活性域の腐食速 度と自然電位とはよく対応していたが，この水素発生反 応の電位依存性によってよく説明される。以上のと括り 

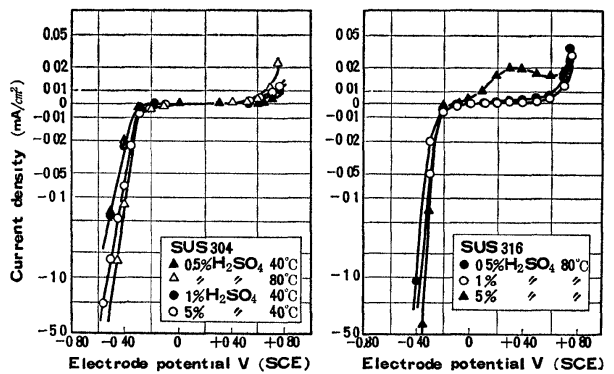

Fig. 9. Cathodic polarization curves of SUS 304 and SUS 316 from $+0.8 \mathrm{~V}$ (SCE) in various conditions of sulfuric acid solution.

硫酸水溶液中の陰分極曲線から, 陰極反応としては水素 発生反応の影響がきわめて大きく，それ以外のたと学ば 溶存酸素還元反応等の寄与はきわめて小さいといえる。

\section{4. 考察}

今回の浸漬腐食試験結果ならびに電気化学的な測定結 果から, 各種硫酸溶液中のステンレス鋼の挙動を考察し てみた。浸漬腐食試験によって鋼種や腐食環境の影響が 明らかになったが，自然電位の測定や陽分極曲線の測定 からも, 鋼種と硫酸溶液との関係が判明し, 不働態の成 否によって耐食性が左右されることが確認された。自然 電位が $-0.15 \mathrm{~V}$ (SCE) 以下になるような鋼種と環境の 組合わせでは，活性溶解を示し，その腐食速度は自然電 位が卑であるほど大さく，たとえば $-0.30 \mathrm{~V}$ (SCE) 以 下では $2 \mathrm{~g} / \mathrm{m}^{2} \cdot \mathrm{hr}$ 以上の腐食を示す。一方，自然電位が $-0.15 \mathrm{~V}(\mathrm{SCE})$ 以上になるような鋼種と環境の組合わ せでは, 電気化学的にも安定な不働態を示し, 腐食速度 も $0.1 \mathrm{~g} / \mathrm{m}^{2} \cdot \mathrm{hr}$ 以下になる。不働態の成否には硫酸濃 度，温度も影響するが，合金元素ではとくに $\mathrm{Cr}$ と $\mathrm{Mo}$ の効果が顕著である。

今回の硫酸溶液中の不働態の成立について考えてみる と，すでによく知られているとおり，いわゆる不働態化 指数 ${ }^{51} p$ が 1 以上でなければならない。

$$
p=i_{c \backslash E p\rangle} / I_{p}
$$

$i_{c(E p)}$ ：不働態化電位 $E_{p}$ に括恬る院極電流密度。

$I_{p}:$ 金属の不働態化電流密度。

今回のような水素還元反応が主体をなす環境において もステンレス鋼が不働態化する事実は，硫酸濃度や温度 ならびに鋼種によっては，水素還元の電流密度が鋼の不 働態化電流密度以上になっていることを示している。す なわち水素還元反応が不働態化作用を発揮するケースが
硫酸濃度や温度，さらに鋼種によっては十分ありらるこ とが判明した。さらにこのような水素還元反応による不 働態化に対して, 高 $\mathrm{Cr}$ 鋼や $\mathrm{Mo}, \mathrm{Cu}$ 等の合金元素の効 果が著しいことが判明した。

\section{5. 結言}

JIS 規格の含 Mo オーステナイトステンレス鋼を中心 に耐硫酸性を検討して次のことが判明した。

（1）浸漬腐食試験, 自然電位の測定, 陽分極曲線の 測定から，鋼種ごとに 使用可能な硫酸濃度-温度条件を 決定した。すぐれた耐硫酸性は不働態の成立によっても たらされ，鋼種と環境条件の組合わせできまる。硫酸溶 液中でのステンレス鋼の使用にあたっては，不働態にな る鋼種選択が重要で, この観点から不働態成立条件の広 い高 $\mathrm{Cr}$ 含 $\mathrm{Mo}$ 鋼が有利である。

（2）硫酸溶液中での不動態の成立に対しては，合金 元素の影響が大きく，高 $\mathrm{Cr}$ が最も効果的で，ついで $\mathrm{Mo}$ や $\mathrm{Cu}$ の効果が大きい。不働態を阻害するものとし ては，環境側では温度上昇の影響が最も大きく，ついで 硫酸濃度が影響する。一方活性域の腐食速度は高 $\mathrm{Cr}$ 鋼 で大きく，高 Mo 鋼では小さくなる。

(3) SUS 304, SUS 316 等のオーステナイトステン レス鋼は，硫酸溶液の濃度や温度いかんでは陰極反応の 水素還元反応によって不働態化するものと思われる。ま た活性域の腐食速度も水素還元反応によって支配され る。

（4）硫酸溶液中の浸漬腐食試験で $0.1 \mathrm{~g} / \mathrm{m}^{2} \cdot \mathrm{hr}$ 以下 の腐食を示す場合には, 自然電位も $0.15 \mathrm{~V}$ (SCE) 以上 の貴な值を示し，分極曲線も安定な不働態の成立を示 す。逆に分極曲線の型が安定な不働態を示す条件におい ても，浸漬腐食試験で注ぼ $1 \mathrm{~g} / \mathrm{m}^{2} \cdot \mathrm{hr}$ 程度の腐食を示 す場合がある。

(Received January 18, 1974)

\section{文献}

1) 長谷川正義編：“ステンレス鋼便覽”（日刊工業 新聞社), p. 146.

2) H. Brearley: Iron \& Steel, July, 309 (1950).

3) 水野 誠: “岡本剛教授退官記念論文集”, p. 51 (1969).

4) 安保秀雄ほか：防食技術，23, 303 (1974).

5）荒木 透核か編：“鉄鋼腐食科学”(朝倉書店), p. 118. 